\title{
HUMANITIES IN HUNGARY LOSE A BENCHMARK OF A SCHOLAR IN MEMORIAM MIHÁLY SZEGEDY-MASZÁK
}

\author{
ISTVÁN DOBOS \\ University of Debrecen \\ idobos@puma.unideb.hu
}

Mihály Szegedy-Maszák, Professor Emeritus of Eötvös Loránd Tudományegyetem (Budapest, Hungary) and Indiana University (Bloomington, Indiana), regular member of Magyar Tudományos Akadémia [Hungarian Academy of Sciences], Academia Europaea (London), International Comparative Literature Association, and Nemzetközi Magyarságtudományi Társaság [International Association for Hungarian Studies], editor-in-chief of the periodical publication Hungarian Studies, recipient of Széchenyi Prize, and a scholar of international stature, passed away at the age of 74 .

His passing is a sad and tremendous loss to the entire Hungarian academic community. The lifework of Mihály Szegedy-Maszák is not only incomparably extensive: it covers an exceptionally long and exciting time period and several academic fields, which makes it particularly significant in our age. He exerted a unique influence on Hungarian literary interpretation of the past 50 years through his groundbreaking literary-history monographs, his studies on theory and methodology, and his related textbooks. Well before his time and the change of the political regime in Hungary, he pioneered in re-evaluating the officially prescribed and forcibly imposed literary canons and in debunking and deconstructing the ideological concept of literature that narrows interpretation possibilities, thus facilitating the acceptance of formerly unjustly effaced authors, such as Zsigmond Kemény, Dezső Kosztolányi, Sándor Márai, and Géza Ottlik.

He prompted not just one but at least two outstanding shifts in the approaches and attitudes prevalent in Hungarian literary scholarship. First, he became a leading voice through propagating and further developing the consequences of the text-centered reading techniques so popular in the 1970's, and then he was also instrumental in disseminating the hermeneutical approach following the introduction of the reading techniques resulting from Ricoeur's "linguistic turn."

The decisive part Mihály Szegedy-Maszák played in the history of literary scholarship was exceptional mainly because he filled it only with the gravity of his mental and intellectual achievement. With the help of his bold and consistent professional commitment, he efficiently counterweighed the one-sided features of 
eternal realism and artistic mirroring/reflection. Among his theoretical achievements, an outstanding accomplishment was the establishment of modern rhetoric, while in the field of prose poetics, he excelled in combining morphology, i.e., the components of narration, and reception.

He was a scholar with an extraordinary range of vision and an impressive amount of factual knowledge, both of which he had acquired in a creative fashion, yet even the structure of his erudition was unique, which he used with inimitable ingenuity while exploring the less familiar contexts of Hungarian literary pieces through introducing surprisingly novel and daring perspectives of interpretation. Mihály Szegedy-Maszák established and developed the poetics of meaning-generating language, based upon the reading experience of works written not only in Hungarian but also in English, French, and German. It was an exceptionally rare feature on his part as a literary scholar that he could also freely and adroitly discuss issues in music while he was also at ease in the realms of fine arts, the humanities, and theology. His up-to-date expertise in questions of theory and methodology was complemented with a prodigious memory of historical facts and figures. Mihály Szegedy-Maszák was equally prolific and remarkable as a scholar of comparative literature, translation theory, the history of ideas, the history of the Hungarian and the English novel in the $19^{\text {th }}$ and $20^{\text {th }}$ centuries, and the critical edition of classical texts. He published seventeen books in Hungarian, one in English, and he was also the co-author of several other volumes of scholarly material.

He was a brilliant literary scholar who cherished traditions yet, at the same time, undertook the task of subjecting the outstanding achievements of Hungarian and European culture to comparative analysis with a truly notable degree of intellectual openness. He was extremely active in his efforts exerted at the internationally recognized fora of academic activities to make our literature and Hungarian culture overall more readily available and accessible to a broad international readership. He regarded literary history not as a closed container but rather as a process, the course of which a practitioner could delve into as determined by the correlations of effects of his/her age. It was from him that we could learn that the reinterpretation of texts is the key to the proper handing down of traditions to future generations.

He deemed it essential that all researchers consider it an eternal task for themselves to check and expand their individual sets of academic tools. He was also a literary scholar who created new ways of expression. His objective manner of discussion was exceptionally rich in expressing various shades of conditionality. He always left some space open for the expression of opinions other than his own. Polite even in the tensest of situations, he always regarded the respect of the dignity of the other's opinion to be the single pattern of academic behavior to be followed. 
The literary figure closest to Mihály Szegedy-Maszák’s intellectual stature was Dezső Kosztolányi, whose ideal concerning Hungarianness he consistently pursued and represented by identifying the Hungarian nation as a language community. It was the unity and topicality of his academic and teaching achievements that made it possible for the publishing house Kalligram Kiadó to launch a continuous series of re-publications of his selected and systematized works as of 2007.

He taught his students and younger colleagues a great deal about the importance of mental and spiritual independence. His requirements in this respect were rather stringent though: he always appreciated individual professional achievements unconditionally. Those of us who were close enough to him to see the effects of his illness towards the end could also notice his stature and eminence as a human being. He was the one who gave us consolation. He was the one who furnished strength to those around him filled with concern by showing an example of dignity in the face of ordeals and trials.

Mihály, dear friend and teacher, may God be with you, as your spirit will always be with us. 